\title{
PENGARUH HIPERTENSI TERHADAP DISFUNGSI EREKSI
}

\author{
${ }^{1}$ Edmond Kevin Rainier Antou \\ ${ }^{2}$ Lusiana Satiawati \\ ${ }^{2}$ Lydia Tendean
}

\author{
${ }^{1}$ Kandidat Skripsi Fakultas Kedokteran Universitas Sam Ratulangi Manado \\ ${ }^{2}$ Bagian Biologi Fakultas Kedokteran Universitas Sam Ratulangi Manado
}

\begin{abstract}
Hypertension is a condition where a person experiences an increase in blood pressure above normal on examination of blood pressure.Research by the Ministry of Health of the Republic of Indonesia in 2009, the prevalence of hypertension in Indonesia in 2007 reached $32.2 \%$, while $30.5 \%$ occurred in the North of Sulawesi. Erectile dysfunction is the inability to maintain an erection that is experienced by men due to various factors. Uncontrolled hypertension can damage blood vessels, causing blood vessels lose their elasticity and the volume of blood that flows to the penis during erection. The purpose of the study to determine the effects and erectile dysfunction and treatment in hypertensive men. The method used is descriptive research method. The research took place in the Hypertension Clinic (Internal Medicine) Government General Hospital of Prof. Dr. R. D. Kandou Manado. Samples taken in the study were hypertensive men with the age group 40-65 years. The research is conducted by using the IIEF- 5 questionnaire. The number of samples obtained 45 patients with hypertension, with the following results: 11 mild erectile dysfunction (24\%), moderate-mild dysfunction 19 people (42\%), moderate dysfunction 12 people (27\%), severe dysfunction 3 people (7\%). This research concludes that all men participating in research, is having an erectile dysfunction.

Keywords: Hypertension, Erectile Dysfunction.
\end{abstract}

\begin{abstract}
Abstrak: Hipertensi adalah keadaan dimana seseorang mengalami peningkatan tekanan darah di atas normal pada pemeriksaan tekanan darah. Riset Depkes RI 2009, prevalensi hipertensi di Indonesia pada tahun 2007 mencapai angka 32.2\%, sedangkan Sulawesi Utara 30.5\%. Disfungsi ereksi adalah ketidakmampuan mempertahankan ereksi yang dialami oleh pria karena berbagai faktor.Hipertensi tidak terkontrol dapat merusak pembuluh darah, menyebabkan pembuluh darah kehilangan elastisitasnya dan volume darah yang dialirkan ke penis saat ereksi.Tujuan penelitian untuk mengetahui disfungsi ereksi serta pengaruh dan penanganannya pada pria hipertensi.Metode penelitian yang digunakan adalah metode penelitian deskriptif.Tempat penelitian dilakukan di Poliklinik Hipertensi (Ilmu Penyakit Dalam) RSUP. Prof. Dr. R. D. Kandou Manado. Sampel yang diambil dalam penelitian adalah pria hipertensi dengan kelompok usia 40-65 tahun. Penelitian menggunakan kuesioner IIEF-5. Jumlah sampel yang didapat 45 penderita hipertensi, dengan hasil penelitian sebagai berikut: disfungsi ereksi ringan 11 orang (24\%), disfungsi sedang-ringan 19 orang (42\%), disfungsi sedang 12 orang (27\%), disfungsi berat 3 orang (7\%). Kesimpulan yang diperoleh dari penelitian ini adalah semua sampel penelitian, mengalami disfungsi ereksi
\end{abstract}

Kata-kata kunci: Hipertensi, Disfungsi ereksi.

Hipertensi atau tekanan darah tinggi adalah suatu keadaan seseorang mengalami peningkatan tekanan darah di atas normal pada pemeriksaan tekanan darah. Penyakit ini dikategorikan sebagai the silent disease karena penderita tidak mengetahui dirinya mengidap hipertensi sebelum memeriksakan tekanan darahnya. ${ }^{1}$ Berdasarkan criteria Joint National Committee on Prevention, Detection, Evaluation, and Treatent on High Blood Pressure VII (JNC VII) yang diterapkan di Indonesia, seseorang dikatakan menderita hipertensi jika tekanan 
darahnya sama dengan atau lebih dari 140/90 mmHg. ${ }^{1,2}$

Data WHO tahun 2000 menunjukkan di seluruh dunia, sekitar 972 juta orang atau $26,4 \%$ mengidap dengan perbandingan 26,6\% pria dan 26,1\% wanita. Angka ini kemungkinan akan meningkat menjadi 29,2\% di tahun 2025. Dari 972 juta pengidap hipertensi, 333 juta berada di negara maju dan 639 juta sisanya berada di negara sedang berkembang, termasuk Indonesia. ${ }^{2}$

Berdasarkan riset Depkes RI 2009, prevalensi hipertensi di Indonesia di Indonesia pada tahun 2007 mencapai angka $32,2 \%$, sedangkan di Sulawesi utara, prevalensi hipertensi sebesar 30,5\%. ${ }^{1}$ Menurut Joint National Committee on Prevention, Detection, Evaluation, and Treatent on High Blood Pressure VII (JNCVII) Amerika Serikat, hampir 1 milyar orang menderita hipertensi di dunia. ${ }^{3}$ Pembuluh darah dan aliran darah yang sehat merupakan syarat esensial untuk memper-oleh dan mempertahankan ereksi. Hipertensi yang tidak terkontrol dapat merusak pembuluh darah di dalam tubuh, sehingga mereka pun kehilangan elastisitasnya dan kurang mampu lagi untuk mengalirkan darah dengan volume yang sama dengan cepat, terutama ke arah penis saat ereksi. ${ }^{4}$

Penelitian tentang disfungsi ereksi pada penderita hipertensi belum banyak dilakukan di Indonesi terutama Manado. Berdasarkan hal tersebut penulis tertarik untuk melakukan penelitian tentang pengaruh hipertensi terhadap disfungsi ereksi pada pria.

\section{METODE PENELITIAN}

Penelitian ini adalah penelitian deskriptif. Jumlah sampel yang didapatkan sebanyak 45 sampel Sampel yang menjadi penelitian harus memenuhi kriteria inklusi dan kriteria sebagai berikut:

- Kriteria Inklusi

- $\quad$ Pria hipertensi, TD $\geq 140 \mathrm{~mm} / \mathrm{Hg}$

- Usia 40-65 tahun

- $\quad$ Pria yang sudah menikah
- $\quad$ Bersedia menjadi objek penelitian

- $\quad$ Kriteria Eksklusi

- Mempunyai riwayat penyakit DM, infertile, kelainan jaringan penis, trauma akut testis, undesensus testis

- Tidak bersedia menjadi subjek penelitian

Penelitian dilakukan di R.S.U.P PROF. Dr. R. D. Kandou Manado, dilaksanakan pada bulan November 2013- Januari 2014. Penelitian ini dilakukan dengan mengisi kuesioner baku IIEF-5 yang telah dimodifikasi menjadi 6 kepada sampel yang telah ditentukan.

\section{HASIL PENELITIAN}

Seluruh sampel telah memenuhi kriteria inklusi penelitian. Pada penelitian ini didapatkan jumlah sampel 45 orang, dan dibagi berdasarkan kategori usia 40-45 tahun sebanyak 4 orang, 46-55 tahun sebanyak 13 orang, 56-65 tahun 28 orang. Setelah dilakukan penelitian dengan pembagian kuesioner baku IIEF-5 yang telah dimodifikasi menjadi 6 (Indeks Internasional Ereksi) didapatkan kesimpulan hasil mengenai fungsi ereksi pada penderita penyakit hipertensi.

Tabel 1. Distribusi pengaruh hipertensi dengan disfungsi ereksi (hasil skor IIEF) berdasarkan kelompok usia

\begin{tabular}{lcc}
\hline \multirow{2}{*}{ Fungsi Ereksi } & \multicolumn{2}{c}{ Responden } \\
\cline { 2 - 3 } & $\mathbf{N}$ & $\mathbf{\%}$ \\
\hline Normal & 0 & 0 \\
Disfungsi ringan & 10 & 22 \\
$\begin{array}{l}\text { Disfungsi } \\
\text { sedang-ringan }\end{array}$ & 21 & 47 \\
$\begin{array}{l}\text { Disfungsi } \\
\text { sedang }\end{array}$ & 11 & 24 \\
$\begin{array}{l}\text { Disfungsi berat } \\
\text { Total }\end{array}$ & 3 & 7 \\
\hline
\end{tabular}

\section{HIPERTENSI}

\section{Definisi}

Hipertensi atau penyakit darah tinggi sebenarnya adalah suatu gangguan pada 
pembuluh darah yang mengakibatkan suplai oksigen dan nutrisi yang dibawa oleh darah terhambat sampai ke jaringan tubuh yang membutuhkan.Hipertensi sering kali disebut sebagai pembunuh gelap (Silent Killer), karena termasuk penyakit yang mematikan tanpa disertai dengan gejala-gejalanya lebih dahulu sebagai peringatan bagi korbannya.Tekanan darah tinggi terjadi bila terus-menerus berada pada 140/90 $\mathrm{mmHg}$ atau lebih. ${ }^{5}$

\section{Etiologi}

\section{Hipertensi primer}

Hipertensi primer (esensial) adalah jenis hipertensi yang paling umum, meliputi sebanyak 90-95\% dari seluruh kasus hipertensi. $^{5}$ Dalam hampir semua masyarakat kontemporer, tekanan darah meningkat seiring dan risiko untuk menjadi hipertensi di kemudian hari cukup tinggi. $^{6,7}$ Hipertensi diakibatkan oleh interaksi gen yang kompleks dan faktor lingkungan. Berbagai gen yang sering ditemukan sedikit berpengaruh pada tekanan darah, sudah diidentifikasi. ${ }^{8}$ Demikian juga beberapa gen yang jarang yang berpengaruh besar pada tekanan darah. ${ }^{9}$ Tetapi dasar genetik dari hipertensi masih belum sepenuhnya dimengerti. Beberapa faktor lingkungan mempengaruhi tekanan darah. ${ }^{10}$ Faktor gaya hidup yang menurunkan tekanan darahdi antaranya mengurangi asupan dalam makanan, meningkatkan konsumsi buahbuahan dan produk rendah lemak (Pendekatan Diet untuk Menghentikan Hipertensi (diet DASH). Olah Raga, ${ }^{11}$ ${ }^{8}$ dan menurunkan asupan juga membantu menurunkan

\section{Hipertensi sekunder}

Hipertensi sekunder terjadi akibat suatu penyebab yang diketahui. Penyakit ginjal adalah penyebab sekunder tersering dari hipertensi. ${ }^{13}$ Hipertensi juga bisa disebabkan oleh kondisi endokrin, seperti sindrom Cushing, hipertiroidisme, hipotiroidisme, akromegali, sindrom atau hiperaldosteronisme, hiperparatiroidisme, dan feokromositoma. ${ }^{14}$

\section{Klasifikasi}

\section{Klasifikasi hipertensi menurut Joint National Commite 7}

Komite eksekutif dari National High Blood Pressure Education Program merupakan sebuah organisasi yang terdiri dari 46 professionalm sukarelawan, dan agen federal. Mereka mencanangkan klasifikasi JNC (Joint Committe on Prevention, Detection, Evaluation, and Treatment of High Blood Pressure) pada Tabel 1, yang dikaji oleh 33 ahli hipertensi nasional Amerika Serikat.

Tabel 2. Klasifikasi Menurut JNC (Joint National Committe on Prevention, Detection, Evaluatin, and Treatment of High Blood Pressure)

\begin{tabular}{lcccc}
\hline $\begin{array}{c}\text { Kategori Tekanan } \\
\text { Darah menurut } \\
\text { JNC 7 }\end{array}$ & $\begin{array}{c}\text { Kategori Tekanan } \\
\text { Darah menurut } \\
\text { JNC 6 }\end{array}$ & $\begin{array}{c}\text { Tekanan Darah } \\
\text { Sistol (mmHg) }\end{array}$ & dan/ atau & $\begin{array}{c}\text { Tekanan } \\
\text { Darah } \\
\text { Diastol } \\
\text { (mmHg) }\end{array}$ \\
\hline $\begin{array}{cccc}\text { Normal } \\
\text { Pra-Hipertensi }\end{array}$ & Optimal & $<120$ & dan & $<80$ \\
- & Nornal & $120-139$ & atau & $80-89$ \\
- & $<130$ & dan & $<85$ \\
Normal-Tinggi & $130-139$ & atau & $85-89$ \\
Tipertensi: & Hipertensi: & $40-159$ & atau & $90-99$ \\
Tahap 1 & Tahap 1 & $\geq 160$ & atau & $\geq 100$ \\
- & Tahap 2 & $160-179$ & atau & $100-109$ \\
& Tahap 3 & $\geq 180$ & atau & $\geq 110$ \\
\hline
\end{tabular}




\section{Patofisiologi}

Bagi kebanyakan orang dengan hipertensi esensial (primer), peningkatan resistensi terhadap aliran darah (resisten perifer total) bertanggung jawab atas tekanan yang tinggi itu sementara curah jantung tetap normal. ${ }^{14}$ Ada bukti bahwa beberapa orang muda yang menderita pra hipertensi atau "hipertensi perbatasan" memiliki curah jantung yang tinggi, denyut jantung meningkat, dan resistensi perifer yang normal. Kondisi ini disebut sebagai hipertensi perbatasan hiperkinetik. ${ }^{15}$ Para penderita ini mengembangkan fitur yang khas dari hipertensi esensial tetap di kemudian hari saat curah jantung menurun dan resistensi perifer meningkat seiring bertambahnya usia. ${ }^{16}$ Masih diperdebatkan apakah pola ini biasa dialami oleh semua orang yang pada akhirnya mengalami hipertensi. ${ }^{17}$ Masih belum jelas apakah peningkatan konstriksi aktif pembuluh darah memegang peranan dalam hipertensi esensial. ${ }^{18}$ Tekanan nadi (perbedaan antara tekanan darah sistolik dan diastolik) sering meningkat pada orang lanjut usia dengan hipertensi. Pada keadaan ini dapat terjadi tekanan sistolik sangat tinggi di atas normal, tetapi tekanan diastolik mungkin normal atau rendah. Kondisi ini disebut hipertensi sistolik terisolasi. ${ }^{19}$ yang biasanya menyertai penuaan dan dapat diperberat oleh tekanan darah tinggi. ${ }^{20}$ Banyak mekanisme yang sudah diajukan sebagai penyebab peningkatan resistensi yang ditemukan dalam sistem arteri pada hipertensi. ${ }^{21}$ Gangguan dalam penanganan garam dan air pada ginjal, khususnya gangguan sistem reninangiotensin intrarenal. ${ }^{23}$ Abnormalitas sistem saraf simpatis. ${ }^{24}$ Mekanisme tersebut tidak berdiri sendiri dan tampaknya keduanya ikut berperan sampai batas tertentu dalam kebanyakan kasus hipertensi esensial. Juga diduga bahwa disfungsi endotel (gangguan fungsi dinding pembuluh darah) dan peradangan. ${ }^{22}$ Vaskular juga ikut berperan dalam meningkatkan resistensi perifer dan kerusakan pembuluh darah pada hipertensi. ${ }^{23,24}$

\section{Diagnosis}

Diagnosis hipertensi ditegakkan saat pasien menderita tekanan darah tinggi secara persisten. ${ }^{25}$ Biasanya, untuk menegakkan diagnosis diperlukan tiga kali pengukuran sfigmomanometer yang berbeda dengan interval satu bulan. ${ }^{26}$ Pemeriksaan awal pasien dengan hipertensi mencakup anamnesis dan pemeriksaan fisik lengkap. Follow-up juga dapat dilakukan, walaupun kurang ideal, dengan memonitor tekanan darah di rumah selama kurun waktu tujuh hari. ${ }^{27}$

\section{Pengobatan}

Saat ini tersedia beberapa golongan obat yang secara keseluruhan disebut obat antihipertensi, untuk pengobatan hipertensi. Risiko kardiovaskuler (termasuk risiko infark miokard dan stroke) dan hasil pemeriksaan tekanan darah menjadi pertimbangan ketika meresepkan obat.Di Kanada semua obat ini, kecuali penghambat reseptor alfa, dianjurkan sebagai lini pertama yang dapat digunakan. $^{28}$

\section{Kombinasi obat}

Banyak orang memerlukan lebih dari satu obat untuk mengendalikan hipertensi mereka. Pedoman JNC7 dan ESHESC menyarankan untuk memulai pengobatan dengan dua macam obat apabila tekanan darah lebih dari $20 \mathrm{mmHg}$ di atas target tekanan darah sistolik atau lebih dari $10 \mathrm{mmHg}$ di atas target diastolik. ${ }^{29}$ Kombinasi yang lebih dipilih adalah penghambat sistem renin-angiotensin dengan antagonis kalsium atau penghambat sistem renin-angiotensin dengan diuretik. Kombinasi yang dapat digunakan adalah sebagai berikut:

- Penghambat kanal kalsium dengan diuretik

- Penghambat beta dengan diuretik

- Penghambat reseptor beta dan obat antiadrenergik. $^{30}$

Meskipun nyaman dikonsumsi, obat-obatan tersebut sebaiknya tidak diberikan untuk 
pasien yang biasa menjalani terapi dengan komponen obat tunggal. $^{31}$

\section{Pencegahan}

Dianjurkan perubahan gayahidup untuk menurunkan tekanan darah, sebelum memulai terapi obat. Pedoman British Hypertension Society 2004 mengajukan perubahan gaya hidup yang konsisten dengan pedoman dari US National High BP Education Program tahun 2002 untuk pencegahan utama bagi hipertensi sebagai berikut:

- Menjaga berat badan normal (misalnya, indeks massa tubuh $20-25 \mathrm{~kg} / \mathrm{m}^{2}$ ).

- Mengurangi asupan diet yang mengandung natrium sampai $<100 \mathrm{mmol} / \mathrm{hari}$ ( $<6$ gr natrium klorida atau $<2,4$ gr natrium per hari).

Cukup banyak orang yang mengalami hipertensi tetapi tidak menyadarinya. Dianjurkan perubahan gaya hidup untuk menurunkan tekanan darah, sebelum memulai terapi obat. Pedoman British Hypertension Society 2004 mengajukan perubahan gaya hidup yang konsisten dengan pedoman dari US National High BP Education Program tahun 2008 untuk pencegahan utama bagi hipertensi sebagai berikut: ${ }^{32,33}$

- Menjaga berat badan normal (misalnya, indeks massa tubuh $20-25 \mathrm{~kg} / \mathrm{m}^{2}$ ).

- Mengurangi asupan diet yang mengandung natrium sampai $<100 \mathrm{mmol} /$ hari ( $<6 \mathrm{~g}$ natrium klorida atau $<2,4$ g natrium per hari).

\section{DISFUNGSI EREKSI}

\section{Definisi disfungsi ereksi}

Disfungsi Ereksi (impotensi)/ Erectile Dysfunction (ED) adalah ketidakmampuan untuk mencapai atau menjaga ereksi tetap pada waktu penetrasi. ${ }^{34}$ Disfungsi ereksi (DE) adalah bentuk gangguan fungsi seksual laki-laki yang sangat umum.Seorang pria yang mengalami disfungsi ereksi kesulitan menjaga ereksi penisnya pada setiap tahap hubungan seksual.

\section{Etiologi}

Penyebab disfungsi ereksi dapat fisik (Organik), psikologis (Psikogenik) atau keduanya. Faktor fisik dapat menyebabkan sekitar 60-80\% kasus DE (Disfungsi Ereksi). Kemung-kinan penyebab fisik Inflamasi prostat (prostatitis).

- Penyakit parah (anemia, tuberkulosis, pneumonia, dll).

- Penyakit jantung, hipertensi, aterosklerosis, diabetes.

- Operasi (mis. operasi kanker prostat).

\section{Faktor resiko}

Berbagai faktor risiko yang dapat memberi berkontribusi masalah disfungsi ereksi,diantaranya:

- Kondisi medis tertentu, terutama diabetes dan masalah jantung.

- Merokok dapat menyebabkan masalah kesehatan kronis yang menyebabkan disfungsi ereksi.

- Bersepeda terlalu lama dapat menekan saraf yang dapat mempengaruhi aliran darah ke penis sehingga menyebabkan disfungsi ereksi sementara. ${ }^{36}$

\section{Diagnosa}

- Anamnesis dan pemeriksaan fisik Untuk mendiagnosa penyebab disfungsi ereksi, anamnesis seputar penyakit dan kondisi yang bias berperan serta dalam disfungsi ereksi dan obat-obatan yang digunakan. ${ }^{37}$ Pemeriksaan fisik umum, termasuk pemeriksaan organ kelamin dan prostat dilakukan. Mengukur tekanan darah pada kaki, menghitung detak pada kaki dan tangan bias mengungkap masalah pada pembuluh arteri.

- Pemeriksaan penunjang

- Pemeriksaan laboratorium (darah)

- Pemeriksaan USG

- Pemeriksaan gula darah untuk diabetes

- Pemeriksaan kadar TSH 


\section{Pengobatan}

Nutrisi yang dibutuhkan: Calcium, Zinc, Cordyceps, Beneficial dan Vitality. Impotensi biasanya bisa diobati tanpa pembedahan dan jenis pengobatan tergantung kepada penyebabnya. Latihan khusus dilakukan oleh penderita impotensi akibat masalah psikis, yaitu yang disebut Teknik pemusatan sensasi 3 tahap. ${ }^{37}$ Teknik ini mendorong hubungan intim dan kehangatan emosional, yang lebih menitikberatkan kepada membangun sebuah hubungan:

- Tahap I: Bercumbu, pasangan berkonsentrasi untuk menyenangkan satu sama lain tanpa menyentuh daerah kemaluan.

- Tahap II : Pasangan mulai menyentuh daerah kemaluan atau daerah erotis lainnya, tetapi belum melakukan hubungan badan.

- Tahap III : Melakukan hubungan badan.

\section{Pencegahan}

Cara terbaik untuk mencegah disfungsi ereksi adalah dengan menjalankan gaya hidup sehat dan mengontrol masalah kesehatan yang Anda miliki. ${ }^{37}$ Berikut ini beberapa hal yang dapat Anda lakukan:

- Rajin konsultasi ke dokter untuk mengontrol diabetes, penyakit jantung atau masalah kesehatan kronis lainnya.

- Lakukan tes medis secara rutin

- Berhenti merokok,menghindari alkohol dan narkoba.

\section{Pengaruh hipertensi terhadap disfungsi ereksi pada pria}

Hipertensi menyebabkan timbulnya resiko kesehatan pada pembuluh darah dan dapatmengakibatkan penyakit yang lebih serius seperti penyakit jantung dan stroke.Pengobatan Obat hipertensi seperti beta blockers dan diuretik bekerja dengan cara mengurangi dan mempertahankan tekanan darahtetap rendah ketika darah mengalir ke penis. ${ }^{38}$ Hal ini pada akhirnya akan menghambat aliran darah ke penis, dan akibatnya pasien hipertensi sering mengalami kesulitan mendapatkan dan mempertahankan ereksi, sehingga terjadi disfungsi ereksi.

\section{SIMPULAN}

Terdapat hubungan antara hipertensi dan disfungsi ereksi pada pria. Hal ini Nampak pada hasil penelitian dimana 45 reponden dengan hipertensi, 45 orang diketahui mengalami disfungsi ereksi berdasarkan kuesioner IIEF-5 yang telah dimodifikasi menjadi 6 (International Index of Erectile Function).

\section{DAFTAR PUSTAKA}

1. Szukri, M., Pranawa. 2001. Terapi Kombinasi dan Anti Hipertensi. Jurnal Kedokteran Syiah Kuala, Vol 1, No 1, Agustus.

2. Asdie, A. Sunarti, Hakimi M. 2007. Hubungan antara Homosistein dan Nitrt Oksid pada Hipertensi esensial di Jawa Tengah, Indonesia. Jurnal Kedokteran Masyarakat.

3. Depkes. (2009). Riset kesehatan dasar (Riskesdas). http://litbang.depkes.go.id

4. Anonim. 7 hal tak terduga penyebab disfungsi ereksi. 2013. http:// www.dechacare.com/ 7-Hal-TakTerduga-Penyebab-Disfungsi-EreksiI1510.htlm.

5. Daftar p Obrien, Eoin; Beevers, D G; Lip, Gregory Y. H.(2007), ABCof hypertension. London: BMJ Books.ISBN 1-4051-3061X.ustaka

6. Carretero OA, Oparil S (January 2000). "Essential hypertension. Part I: Definition and etiology". Circulation 101 (3): 329-35.

7. Vasan, RS; Beiser, A, Seshadri, S, Larson, MG, Kannel, WB, D'Agostino, RB, Levy, D (2002 Feb 27). "Residual lifetime risk for developing hypertension in middle-aged women and men: The Framingham Heart Study.". JAMA: the journal of the American Medical Association 287 (8): 1003-10. .

8. The International Consortium for Blood Pressure Genome-Wide Association Studies. Genetic variants in novel pathways influence blood pressure and cardiovascular 
disease risk. Nature 2011; 478: 103-109 doi:10.1038/nature10405

9. Lifton, RP; Gharavi, AG, Geller, DS (2001 Feb 23). "Molecular mechanisms of human hypertension.". Cell 104 (4): 545-56..

10. He, FJ; MacGregor, GA (2009 Jun). "A comprehensive review on salt and health and current experience of worldwide salt reduction programmes.". Journal of human hypertension 23 (6): 363-84.

11. Dickinson HO, Mason JM, Nicolson DJ, Campbell F, Beyer FR, Cook JV, Williams B, Ford GA. Lifestyle interventions to reduce raised blood pressure: a systematic review of randomized controlled trials. J Hypertens. 2006;24:215-33.

12. Haslam DW, James WP (2005). "Obesity". Lancet 366 (9492): $\quad$ 1197209. doi:10.1016/S0140-6736(05)67483-1.

13. Whelton PK, He J, Appel LJ, Cutler JA, Havas S, Kotchen TA et al. (2002). "Primary prevention of hypertension: Clinical and public health advisory from The National High Blood Pressure Education Program". JAMA 288 (15): 1882-8.doi:10.1001/jama.288.15.1882.

14. O'Brien, Eoin; Beevers, D. G.; Lip, Gregory Y. H. (2007). ABC of hypertension. London: BMJ Books.ISBN 1-4051-3061-X.

15. Dluhy RG, Williams GH. Endocrine hypertension. In: Wilson JD, Foster DW, Kronenberg HM, eds. Williams Textbook of Endocrinology. 9th ed. Philadelphia, Pa: WB Saunders; 1998:729-49.

16. Conway J (April 1984). "Hemodynamic aspects of essential hypertension in humans". Physiol. $\quad$ Rev. 64 (2): 61760Palatini P, Julius S (June 2009). "The role of cardiac autonomic function in hypertension and cardiovascular disease". Curr. Hypertens. Rep. 11 (3): 199-205. .

17. Andersson OK, Lingman M, Himmelmann A, Sivertsson R, Widgren BR (2004). "Prediction of future hypertension by casual blood pressure or invasive hemodynamics? A 30-year follow-up study". Blood Press. 13 (6): 350-4.

18. Schiffrin EL (February 1992). "Reactivity of small blood vessels in hypertension: relation with structural changes. State of the art lecture". Hypertension 19 (2 Suppl): II1-9. PMID 1735561.

19. Chobanian AV (August 2007). "Clinical practice. Isolated systolic hypertension in the elderly". N. Engl. J. Med. 357 (8): 78996.doi:10.1056/NEJMcp071137. .

20. Zieman SJ, Melenovsky V, Kass DA (May 2005). "Mechanisms, pathophysiology, and therapy of arterial stiffness". Arterioscler. Thromb. $\quad$ Vasc. Biol. 25 (5): $932-$ 43. doi:10.1161/01.ATV.0000160548.7831 7.29.

21. Navar LG (December 2010). "Counterpoint: Activation of the intrarenal renin-angiotensin system is the dominant contributor to systemic HYPERLINK

"http://www.ncbi.nlm.nih.gov/pmc/articles/ PMC3006411" HYPERLINK "http://www.ncbi.nlm.nih.gov/pmc/articles/ PMC3006411" HYPERLINK "http://www.ncbi.nlm.nih.gov/pmc/articles/ PMC3006411"hypertension". J. Appl. Physiol. 109 (6): 1998-2000; discussion 2015. doi: $\quad$ 10.1152/japplphysiol. 00182.2010a.PMC 3006411.

22. Esler $M$, Lambert $E$, Schlaich $M$ (December 2010). "Point: Chronic activation of the sympathetic nervous system is the dominant contributor to systemic hypertension". J. Appl. Physiol. 109 (6): 1996-8; discussion 2016. doi:10.1152/japplphysiol.00182.2010

23. Versari D, Daghini E, Virdis A, Ghiadoni L, Taddei S (June 2009). "Endotheliumdependent contractions and endothelial dysfunction in human hypertension". Br. J. Pharmacol. 157 (4):

$527-$

36. doi:10.1111/j.14765381.2009.00240.x.PMC 2707964. .

24. Marchesi C, Paradis P, Schiffrin EL (July 2008). "Role of the renin-angiotensin system in vascular inflammation". Trends Pharmacol. Sci. 29 (7): 36774. doi:10.1016/ j.tips.2008.05.003. .

25. National Clinical Guidance Centre (August 2011). "7 Diagnosis of Hypertension, 7.5 Link from evidence to recommendations". Hypertension (NICE CG 127). National Institute for Health and Clinical Excellence. hlm. 102. Diakses 2011-12-22.

26. Nelson, Mark. "Drug treatment of elevated blood pressure". Australian Prescriber (33): 108-112. Diakses August 11, 2010.

27. Eni C. Okonofua; Kit N. Simpson; Ammar Jesri; Shakaib U. Rehman; Valerie L. Durkalski; Brent M. Egan (January 23, 2006)."Therapeutic Inertia Is an 
Impediment to Achieving the Healthy People 2010 Blood Pressure Control Goals". Hypertension 47(2006;47:345):345 551.doi:10.1161/01.HYP.0000200702.7643 6.4b.PMID 16432045. Diakses 2009-11-22.

28. $\wedge \wedge^{\mathrm{a} b \mathrm{c}}$ Klarenbach, SW; McAlister, FA, Johansen, H, Tu, K, Hazel, M, Walker, R, Zarnke, KB, Campbell, NR, Canadian Hypertension Education, Program (2010 May). "Identification of factors driving differences in cost effectiveness of first-line pharmacological therapy for uncomplicated hypertension.". The Canadian journal of cardiology 26 (5):

e15863. PMID 20485695.

29. Chobanian AV, Bakris GL, Black HR, et al. (December 2003). "Seventh report of the Joint National Committee on Prevention, Detection, Evaluation, and Treatment of High Blood Pressure". Hypertension 42 (6): 1206-52.doi:10.1161/01.

HYP.0000107251. 49515.c2. PMID 14656957.

30. Sever PS, Messerli FH (October 2011). "Hypertension management 2011: optimal combination therapy". Eur. Heart J. 32(20): 2499-506. doi:10.1093/eurheartj/ehr177.

31. British National Formulary. No. 62. September 2011. Diakses 2011-1222. ${ }^{\text {ab }}$ Musini VM, Tejani AM, Bassett K, Wright JM (2009). "Pharmacotherapy for hypertension in the elderly". In Musini, Vijaya M.Cochrane Database Syst Rev (4): CD000028. : : :10.1002/14651858.CD0000 28.pub2

32. Williams, B; Poulter, NR, Brown, MJ, Davis, M, McInnes, GT, Potter, JF, Sever, PS, McG Thom, S, British Hypertension, Society (2004 Mar). "Guidelines for management of hypertension: report of the fourth working party of the British Hypertension Society, 2004-BHS IV.". Journal of human hypertension 18 (3): 139-85.

33. Whelton PK et al. (2002). "Primary prevention of hypertension. Clinical and public health advisory from the National High Blood Pressure Education Program". JAMA 288 (15): $\quad$ 18821888. doi:10.1001/jama.288.15.1882.

34. JP: Sabtu, 23-1-2010: "DE (Disfungsi Ereksi) Gangguan Pembuluh Darah" Hal. 48)

35. Anonym. Penyebab dan terapi disfungsi ereksi. http://majalahkesehatan.com/penyebabdan-terapi-disfungsi-ereksi/

36. Boyke. Disfungsi ereksi dan pengobatannya.

http://seksualitasnews.com/disfungsiereksi-dan-pengobatannya.html

37. Anonym. Disfungsi ereksi. http://id.wikipedia.org/wiki/Disfungsi_erek si

38. Obat hipertensi sebabkan disfungsi ereksi. http://naturindonesia.com/hypertensi/1048obat-hipertensi-sebabkan-disfungsiereksi.pdf 